\title{
Total flavonoids from Plumula Nelumbinis suppress angiotensin II-induced fractalkine production by inhibiting the ROS/NF-кB pathway in human umbilical vein endothelial cells
}

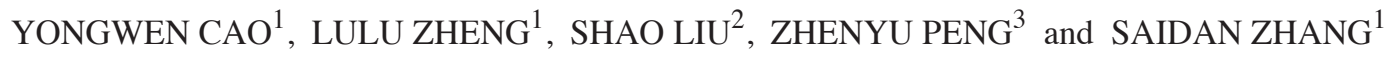 \\ Departments of ${ }^{1}$ Cardiology and ${ }^{2}$ Pharmacology, Xiangya Hospital of Central South University, Changsha, Hunan 410008; \\ ${ }^{3}$ Department of Emergency, The Second Xiangya Hospital of Central South University, Changsha, Hunan 410011, P.R. China
}

Received September 27, 2013; Accepted January 28, 2014

DOI: 10.3892/etm.2014.1554

\begin{abstract}
Angiotensin II (Ang II) is a neuroendocrine factor that promotes hypertension and has been implicated in vascular inflammation through the induction of reactive oxygen species (ROS) and proinflammatory genes in endothelial cells. However, relatively little attention has been paid to the effect of Ang II on fractalkine (FKN), an important chemokine involved in endothelial dysfunction. In the study, we aimed to investigate the protective role of total flavonoids from Plumula Nelumbinis (TFPN), the main component extracted from Semen Nelumbinis, in Ang II-induced oxidative stress injury in human umbilical vein endothelial cells (HUVECs). Furthermore, we studied whether TFPN could attenuate the Ang II-induced generation of ROS and the activation of nuclear factor- $\mathrm{kB}(\mathrm{NF}-\kappa \mathrm{B})$; whether these Ang II-induced effects were inhibited by apocynin (a nicotinamide adenine dinucleotide phosphate oxidase inhibitor) and pyrrolidine dithiocarbamate (an NF- $\mathrm{kB}$ inhibitor). In the present study, it was observed that total flavonoids from Plumula Nelumbinis (TFPN), the main component extracted from Semen Nelumbinis, concentration-dependently inhibited the FKN production induced by Ang II in human umbilical vein endothelial cells (HUVECs). Furthermore, TFPN attenuated the Ang II-induced generation of ROS and the activation of nuclear factor- $\kappa \mathrm{B}(\mathrm{NF}-\kappa \mathrm{B})$; these Ang II-induced effects were also inhibited by apocynin (a nicotinamide adenine dinucleotide phosphate oxidase inhibitor) and pyrrolidine dithiocarbamate (an NF- $\mathrm{kB}$ inhibitor). In conclusion, the findings of the present study indicate that TFPN attenuate Ang II-induced upregulation of FKN by inhibiting the ROS/NF- $\mathrm{KB}$ pathway in HUVECs and thus have a suppressive effect on vascular inflammation.
\end{abstract}

Correspondence to: Professor Saidan Zhang, Department of Cardiology, Xiangya Hospital of Central South University, 87 Xiangya Road, Changsha, Hunan 410008, P.R. China

E-mail: csuzhangsaidan@163.com

Key words: total flavonoids from Plumula Nelumbinis, angiotensin II, reactive oxygen species, nuclear factor- $\kappa \mathrm{B}$, fractalkine, endothelial cells

\section{Introduction}

During the initiation and progression of hypertension, the vascular endothelium is constantly exposed to elevated angiotensin II (Ang II) levels, and certain endotheliocytes undergo oxidative stress, which contributes to endothelial dysfunction.

Reactive oxygen species (ROS), including the hydroxyl radical ( $\left.\mathrm{HO}^{*}\right)$, superoxide anion $\left(\mathrm{O}_{2}{ }^{-}\right)$and hydrogen peroxide $\left(\mathrm{H}_{2} \mathrm{O}_{2}\right)$, are continuously produced as a result of cellular oxidation-reduction processes stimulated by Ang II (1). Moreover, the high levels of Ang II-induced inflammatory factors may be mediated through oxidative stress (2). However, whether fractalkine (FKN), an important chemokine involved in endothelial dysfunction, is induced by Ang II remains unclear.

Plumula Nelumbinis is a type of traditional Chinese herbal medicine. The major components are alkaloids that exhibit a nerve-blocking effect. Thus, Plumula Nelumbinis may be used to treat hypertension (3). However, the role of the flavonoid components of Plumula Nelumbinis in the prevention of hypertension has not previously been studied. Flavonoids are present in a large number of plants and are strong antioxidants that scavenge various types of radicals through their $\mathrm{H}^{+}$-donating properties in aqueous and organic environments (4-8). Previous studies have indicated that flavonoids protect cells against ROS-induced inflammation by increasing the activity of antioxidant enzymes.

The present study investigated the protective role of total flavonoids from Plumula Nemlumbinis (TFPN) in Ang II-induced oxidative stress injury in human umbilical vein endothelial cells (HUVECs). To the best of our knowledge, this is the first time such a study has been conducted. In addition, the molecular mechanisms by which TFPN affect the production of ROS and malondialdehyde (MDA), the activity of superoxide dismutase (SOD) and the expression of nicotinamide adenine dinucleotide phosphate (NADPH) oxidase, I $\mathrm{B}-\alpha$ and $\mathrm{FKN}$ were investigated.

\section{Materials and methods}

Materials. Dulbecco's modified Eagle's medium (DMEM) and fetal bovine serum (FBS) were purchased from Hyclone 
(Logan, UT, USA). Penicillin and streptomycin were obtained from Gibco-BRL (Grand Island, NY, USA). The mouse anti-p47phox and anti-IкB- $\alpha$ primary antibodies were obtained from Anbo Biotechnology, Inc. (Sunnyvale, CA, USA). The mouse anti-FKN primary antibody and rabbit anti-mouse secondary antibodies were purchased from Santa Cruz Biotechnology, Inc. (Santa Cruz, CA, USA). The bicinchoninic acid (BCA) reagent, enhanced chemiluminescence (ECL) kit for western blotting and the fluorescent ROS detection kit were purchased from Beyotime Biotechnology (Shanghai, China). Reagent kits for measuring MDA and SOD were purchased from Jiancheng Bioengineering Institute (Nanjing, Jiangsu, China). Ang II, apocynin, pyrrolidine dithiocarbamate (PDTC), 3-(4,5-dimethylthiazol-2-yl)-2,5-diphenyl tetrazolium bromide (MTT) and dimethyl sulfoxide (DMSO) were purchased from Sigma-Aldrich (St. Louis, MO, USA). The TFPN were extracted from Plumula Nelumbinis by the Department of Pharmacology, Xiangya Hospital of Central South University (Changsha, China).

Cell culture and treatment. HUVECs were purchased from the Cell Culture Center, Xiangya Medical College of Central South University. The HUVECs were cultured in DMEM supplemented with 10\% FBS, $10 \mathrm{mmol} / 1 \mathrm{HEPES}, 100 \mathrm{U} / \mathrm{ml}$ penicillin and $100 \mathrm{mg} / \mathrm{ml}$ streptomycin at $37^{\circ} \mathrm{C}$ in a humidified atmosphere of $5 \% \mathrm{CO}_{2}$ and $95 \%$ air. Endothelial cells in an actively growing condition from the fourth to sixth passages were used for the experiments. One day prior to treatment, $80-85 \%$ confluent cells were incubated with serum-free media for $24 \mathrm{~h}$ to synchronize cell growth. The cells were pretreated with the following drug interventions: $0.05,0.1$ or $0.2 \mathrm{mg} / \mathrm{ml}$ TFPN, $200 \mu \mathrm{M}$ apocynin (an NADPH oxidase inhibitor) and $50 \mu \mathrm{M}$ PDTC (an NF- $\kappa \mathrm{B}$ inhibitor), for $4 \mathrm{~h}$. Next, $10^{-7} \mathrm{~mol} / \mathrm{l}$ Ang II was added to the medium containing the various drugs for an additional $24 \mathrm{~h}$. Each treatment compound was individually dissolved in DMEM, and the cells cultured in the serum-free medium served as controls. The cells were incubated prior to protein isolation or the collection of cultured supernatant for chemical colorimetry. Each individual experiment was replicated at least three times.

Effect of TFPN on HUVEC viability. The effect of TFPN on HUVEC viability was measured by the MTT assay, as previously described (9). HUVECs were counted and seeded into 96-well culture plates at a density of $0.6-1 \times 10^{4}$ cells/well. The cells were pretreated with various concentrations of TFPN $(0.001,0.01,0.025,0.05,0.1,0.2,0.4$ or $0.6 \mathrm{mg} / \mathrm{ml})$ for $4 \mathrm{~h}$. Next, $10^{-7} \mathrm{~mol} / \mathrm{l}$ Ang II was added to the medium, which was incubated for an additional $24 \mathrm{~h}$. Each well was washed twice with PBS, then, for each well, $20 \mu \mathrm{l}$ MTT solution $(5 \mathrm{mg} / \mathrm{ml})$ combined with $180 \mu \mathrm{l}$ serum-free DMEM was added. Following incubation of the plate for $4 \mathrm{~h}$, insoluble formazan crystals were dissolved in $150 \mu \mathrm{l}$ DMSO. The optical density of each well was measured using an ELISA multiplate reader (Infinite 200 PRO multimode reader; Tecan Group Ltd., Männedorf, Switzerland) at $492 \mathrm{~nm}$.

MDA and SOD assays. The cells were cultured in 50-ml tissue culture flasks at a density of $5 \times 10^{5}$ cells $/ \mathrm{ml}$ and allowed to grow to confluence. Following cell treatment as described in Cell culture and treatment, supernatants of the cultures were collected for chemical colorimetry. The cells were washed with PBS, trypsinized for $1 \mathrm{~min}$ at $37^{\circ} \mathrm{C}$, harvested by centrifugation $(3,000 \mathrm{x} \mathrm{g}$ for $10 \mathrm{~min})$ and resuspended in $2 \mathrm{ml}$ PBS. Following ultrasonication at $4^{\circ} \mathrm{C}$, the protein content was determined using the BCA method. The levels of MDA and SOD were determined using assay kits, according to the manufacturer's instructions.

Measurement of $\mathrm{O}_{2}^{-}$generation in intact cells. Changes in intracellular ROS levels were determined by measuring the oxidative conversion of 2',7'-dichlorofluorescein diacetate (DCFH-DA; Invitrogen Life Technologies, Carlsbad, CA, USA), which is cell-permeable, to the fluorescent DCF in a SpectraMax M5 Muti-Mode Microplate Reader (Molecular Devices, Sunnyvale, CA, USA). The treated cells were washed with serum-free media and incubated with $10 \mathrm{mM}$ DCFH-DA at $37^{\circ} \mathrm{C}$ for $20 \mathrm{~min}$. DCF fluorescence was then detected using a fluorospectrophotometer. Fluorescence analysis was measured at $485 \mathrm{~nm}$ excitation and $535 \mathrm{~nm}$ emission. Fluorescence data are expressed as the percentage increase in fluorescence over that of untreated samples.

Western blot analysis. The cells were lysed for $30 \mathrm{~min}$ at $4{ }^{\circ} \mathrm{C}$ in a lysis buffer. The total cell protein concentration was determined using BCA reagent. Total protein $(50 \mu \mathrm{g})$ was resolved by SDS-polyacrylamide gel electrophoresis, transferred to a PVDF membrane and subjected to immunoblot analysis. The primary antibodies for FKN (1:400), p47phox (1:500), ІкB- $\alpha$ $(1: 500)$ and $\beta$-actin $(1: 1,000)$ and rabbit anti-mouse secondary antibodies were used. The bands were visualized using ECL reagents and the relative intensities were determined using a bio-imaging analyzer (ChemiDoc ${ }^{\mathrm{TM}}$ MP System 170-8280; Bio-Rad Laboratories, Inc., Hercules, CA, USA). The densities of the products were quantified using Image Lab 3.0 $0^{\text {beta }}$ (version 3.0; Bio-Rad). All results were representative of at least three independent experiments.

Statistical analysis. Data are expressed as the mean \pm SD and were analyzed by ANOVA, followed by the Newman-Student-Keuls test for multiple comparisons. $\mathrm{P}<0.05$ was considered to indicate a statistically significant difference.

\section{Results}

Effect of TFPN on HUVECs damaged by Ang II. To evaluate whether TFPN protect against oxidative stress, HUVECs were pretreated with various concentrations of TFPN $(0.001,0.01$, $0.025,0.05,0.1,0.2,0.4$ or $0.6 \mathrm{mg} / \mathrm{ml}$ ) for $4 \mathrm{~h}$, and $10^{-7} \mathrm{~mol} / 1$ Ang II was added to the medium for an additional $24 \mathrm{~h}$. Next, cell viability was measured by the MTT assay. As shown in Fig. 1, Ang II markedly decreased the viability of the endothelial cells $(\mathrm{P}<0.01)$, while TFPN, at concentrations between 0.01 and $0.2 \mathrm{mg} / \mathrm{ml}$, protected the cells from Ang II-induced cytotoxicity in a concentration-dependent manner $(\mathrm{P}<0.01)$. The lowest concentration of TFPN $(0.001 \mathrm{mg} / \mathrm{ml})$ did not have a protective effect against Ang II-induced damage on HUVECs $(\mathrm{P}>0.05)$. Higher concentrations of TFPN (0.4 and $0.6 \mathrm{mg} / \mathrm{ml})$ increased the cell survival rate $(\mathrm{P}<0.01)$, but were slightly inferior to $0.2 \mathrm{mg} / \mathrm{ml}$ TFPN. The results indicate 


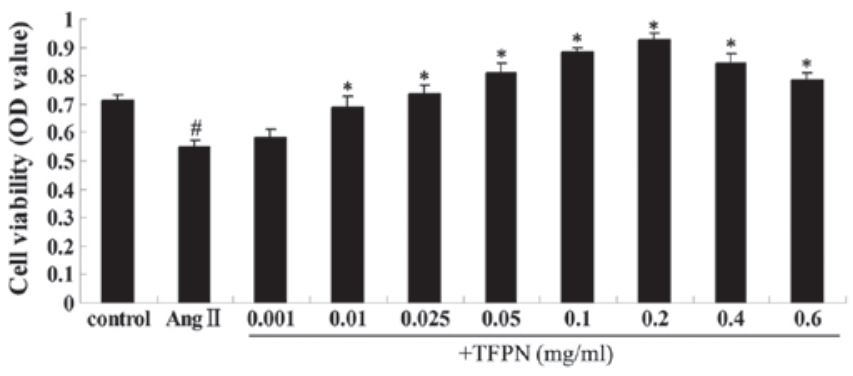

Figure 1. Effect of TFPN on the viability of HUVECs injured by Ang II. Cells were pretreated with various concentrations of TFPN $(0.001,0.01,0.025$, $0.05,0.1,0.2,0.4$ or $0.6 \mathrm{mg} / \mathrm{ml})$ for $4 \mathrm{~h}$. Ang II $\left(10^{-7} \mathrm{~mol} / 1\right)$ was subsequently added to the medium for an additional $24 \mathrm{~h}$. Cell viability was measured by the MTT assay at $492 \mathrm{~nm} .{ }^{*} \mathrm{P}<0.01$, vs. control; ${ }^{*} \mathrm{P}<0.01$, vs. Ang II; $(\mathrm{n}=4)$ + TFPN, Ang II + TFPN; TFPN, total flavonoids of Plumula Nelumbinis; HUVECs, human umbilical vein endothelial cells; Ang II, angiotensin II; MTT, 3-(4,5-dimethylthiazol-2-yl)-2,5-diphenyl tetrazolium bromide.

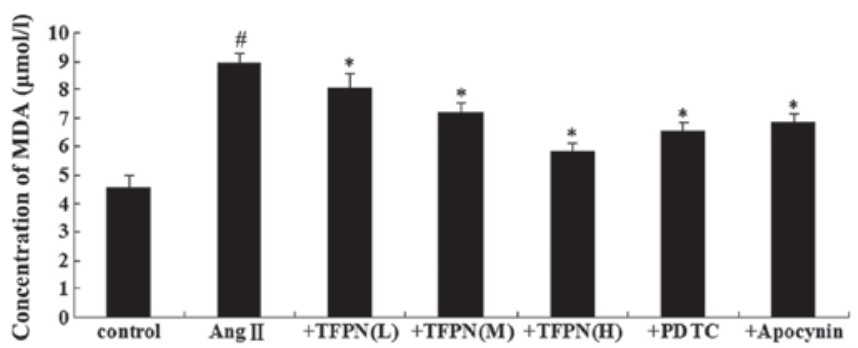

Figure 2. Effect of TFPN on the level of MDA. Cells were pretreated with various concentrations of TFPN $(0.05,0.1$ or $0.2 \mathrm{mg} / \mathrm{ml}), 50 \mu \mathrm{M}$ PDTC or $100 \mu \mathrm{M}$ apocynin for $4 \mathrm{~h}$. Ang II $\left(10^{-7} \mathrm{~mol} / \mathrm{l}\right)$ was added to the medium containing the various drugs for an additional $24 \mathrm{~h}$ prior to protein isolation. " $\mathrm{P}<0.05$, vs control; ${ }^{*} \mathrm{P}<0.05$, vs. Ang II; $(\mathrm{n}=4)$. +TFPN(L), Ang II + $0.05 \mathrm{mg} / \mathrm{ml}$ TFPN; + TFPN(M), Ang II + $0.1 \mathrm{mg} / \mathrm{ml}$ TFPN; +TFPN(H), Ang II $+0.2 \mathrm{mg} / \mathrm{m}$ TFPN; +PDTC, Ang II + PDTC; +Apocynin, Ang II + apocynin; TFPN, total flavonoids of Plumula Nelumbinis; MDA, malondialdehyde; Ang II, angiotensin II; PDTC, pyrrolidine dithiocarbamate.

that TFPN protected HUVECs from Ang II-induced cellular injury.

Effect of TFPN on the level of MDA. To determine the effect of TFPN on the MDA level in Ang II-damaged endothelial cells, the cells were pretreated with TFPN, PDTC or apocyin for $4 \mathrm{~h}$ and then exposed to $10^{-7} \mathrm{~mol} / \mathrm{l}$ Ang II for $24 \mathrm{~h}$. As shown in Fig. 2, incubation of the cells with $10^{-7} \mathrm{~mol} / \mathrm{l}$ Ang II increased the level of MDA $(\mathrm{P}<0.05)$. Compared with the MDA level in Ang II-treated cells, pretreatment with various concentrations of TFPN $(0.05,0.1$ or $0.2 \mathrm{mg} / \mathrm{ml})$ reduced the level of MDA in a concentration-dependent manner $(\mathrm{P}<0.05)$. Pretreatment with $50 \mu \mathrm{M}$ PDTC and $100 \mu \mathrm{M}$ apocynin also reduced the level of MDA $(\mathrm{P}<0.05)$.

Effect of TFPN on SOD activity. To determine the effect of TFPN on SOD activity in Ang II-damaged endothelial cells, the cells were pretreated with TFPN, PDTC or apocyin for $4 \mathrm{~h}$ and then exposed to $10^{-7} \mathrm{~mol} / \mathrm{l}$ Ang II for $24 \mathrm{~h}$. As shown in Fig. 3, incubation of the cells with $10^{-7} \mathrm{~mol} / 1 \mathrm{Ang}$ II decreased the SOD activity $(\mathrm{P}<0.05)$. Compared with the SOD activity in the Ang II-treated cells, pretreatment with various concentrations of TFPN $(0.05,0.1$ or $0.2 \mathrm{mg} / \mathrm{ml})$ increased the

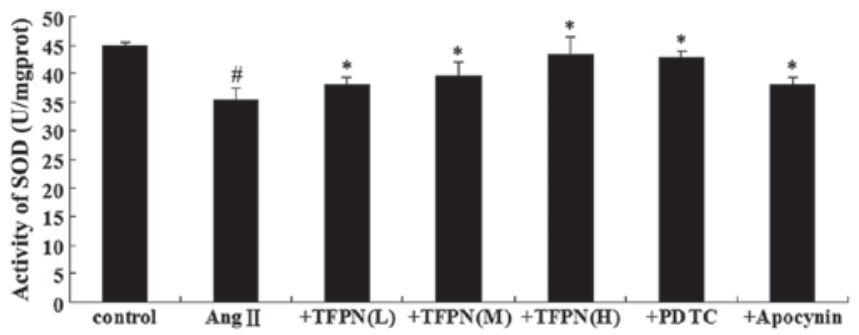

Figure 3. Effect of TFPN on SOD activity. Cells were pretreated with various concentrations of TFPN $(0.05,0.1$ or $0.2 \mathrm{mg} / \mathrm{ml}), 50 \mu \mathrm{M}$ PDTC or $100 \mu \mathrm{M}$ apocynin for $4 \mathrm{~h}$. Ang II $\left(10^{-7} \mathrm{~mol} / \mathrm{l}\right)$ was added to the medium containing the various drugs for an additional $24 \mathrm{~h}$ prior to protein isolation. ${ }^{\#} \mathrm{P}<0.05$, vs. control; * $\mathrm{P}<0.05$, vs. Ang II; $(\mathrm{n}=4)$. $+\mathrm{TFPN}(\mathrm{L})$, Ang II $+0.05 \mathrm{mg} / \mathrm{ml}$ TFPN; +TFPN(M), Ang II + $0.1 \mathrm{mg} / \mathrm{ml}$ TFPN; +TFPN(H), Ang II + 0.2 $\mathrm{mg} / \mathrm{ml}$ TFPN; + PDTC, Ang II + PDTC; +Apocynin, Ang II + apocynin; TFPN, total flavonoids of Plumula Nelumbinis; SOD, superoxide dismutase; Ang II, angiotensin II; PDTC, pyrrolidine dithiocarbamate.

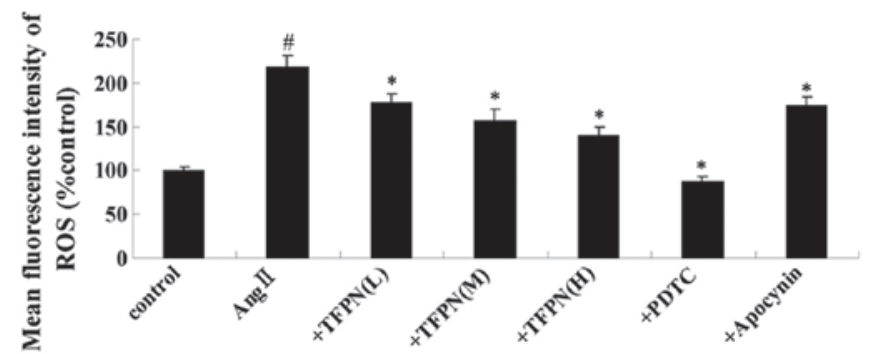

Figure 4. Effect of TFPN on the ROS levels. Cells were pretreated with various concentrations of TFPN $(0.05,0.1$ or $0.2 \mathrm{mg} / \mathrm{ml}), 50 \mu \mathrm{M}$ PDTC or $100 \mu \mathrm{M}$ apocynin for $1 \mathrm{~h}$. Ang II $\left(10^{-7} \mathrm{~mol} / \mathrm{l}\right)$ was added to the medium containing the various drugs for an additional $4 \mathrm{~h}$ prior to mean fluorescence intensity testing. ${ }^{\#} \mathrm{P}<0.01$, vs. control; ${ }^{*} \mathrm{P}<0.01$, vs. Ang II; $(\mathrm{n}=4)$. $+\mathrm{TFPN}(\mathrm{L})$, Ang II + $0.05 \mathrm{mg} / \mathrm{ml}$ TFPN; +TFPN(M), Ang II + $0.1 \mathrm{mg} / \mathrm{ml} \mathrm{TFPN}$; +TFPN(H), Ang II + 0.2 mg/ml TFPN; +PDTC, Ang II + PDTC; +Apocynin, Ang II + apocynin; TFPN, total flavonoids of Plumula Nelumbinis; ROS, reactive oxygen species; Ang II, angiotensin II.

SOD activity in a concentration-dependent manner $(\mathrm{P}<0.05)$. Pretreatment with $50 \mu \mathrm{M}$ PDTC and $100 \mu \mathrm{M}$ apocynin also increased SOD activity $(\mathrm{P}<0.05)$.

Effect of TFPN on ROS levels. To determine the effect of TFPN on the level of ROS in Ang II-damaged endothelial cells, the cells were pretreated with TFPN, PDTC or apocyin for $4 \mathrm{~h}$ and then exposed to $10^{-7} \mathrm{~mol} / \mathrm{l}$ Ang II for $24 \mathrm{~h}$. As shown in Fig. 4, incubation of the cells with $10^{-7} \mathrm{~mol} / \mathrm{l}$ Ang II increased the ROS levels $(\mathrm{P}<0.01)$. Pre-treatment with various concentrations of TFPN $(0.05,0.1$ or $0.2 \mathrm{mg} / \mathrm{ml})$ reduced the levels of ROS in a concentration-dependent manner compared with those in the Ang II-treated cells $(\mathrm{P}<0.01)$. Pretreatment with $50 \mu \mathrm{M}$ PDTC and $100 \mu \mathrm{M}$ apocynin also reduced the levels of $\operatorname{ROS}(\mathrm{P}<0.01)$.

FKN relative protein expression. Western blotting was used to investigate whether FKN protein was upregulated in endothelial cells following treatment with Ang II, and to analyze whether TFPN inhibited this upregulation. As shown in Fig. 5, $10^{-7} \mathrm{~mol} / \mathrm{l}$ Ang II significantly increased the protein expression level of FKN $(\mathrm{P}<0.01)$. With the exception of $0.05 \mathrm{mg} / \mathrm{ml} \mathrm{TFPN}$, pretreatment with TFPN $(0.1$ and $0.2 \mathrm{mg} / \mathrm{ml})$ and pretreatment 

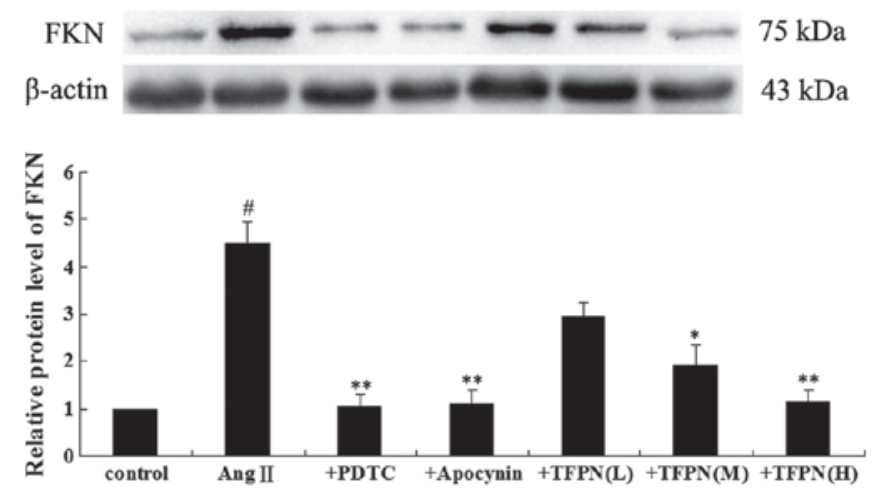

Figure 5. Cells were pretreated with $50 \mu \mathrm{M}$ PDTC, $100 \mu \mathrm{M}$ apocynin and various concentrations of TFPN $(0.05,0.1$ or $0.2 \mathrm{mg} / \mathrm{ml})$ for $4 \mathrm{~h}$. Ang II $\left(10^{-7} \mathrm{~mol} / \mathrm{l}\right)$ was added to the medium containing the various drugs for an additional $24 \mathrm{~h}$ prior to protein isolation. The gels represent the western blot analysis results of FKN protein expression. $\beta$-actin was used as the internal control. " $\mathrm{P}<0.01$, vs. control; " $\mathrm{P}<0.05$, vs. Ang II; ${ }^{* *} \mathrm{P}<0.01$, vs. Ang II; $(\mathrm{n}=3)$. +PDTC, Ang II + PDTC; +Apocynin, Ang II + apocynin; +TFPN(L), Ang II + $0.05 \mathrm{mg} / \mathrm{ml}$ TFPN; +TFPN(M), Ang II + $0.1 \mathrm{mg} / \mathrm{ml}$ TFPN; + TFPN $(\mathrm{H})$, Ang II $+0.2 \mathrm{mg} / \mathrm{ml}$ TFPN; TFPN, total flavonoids of Plumula Nelumbinis; FKN, fractalkine; Ang II, angiotensin II; PDTC, pyrrolidine dithiocarbamate.
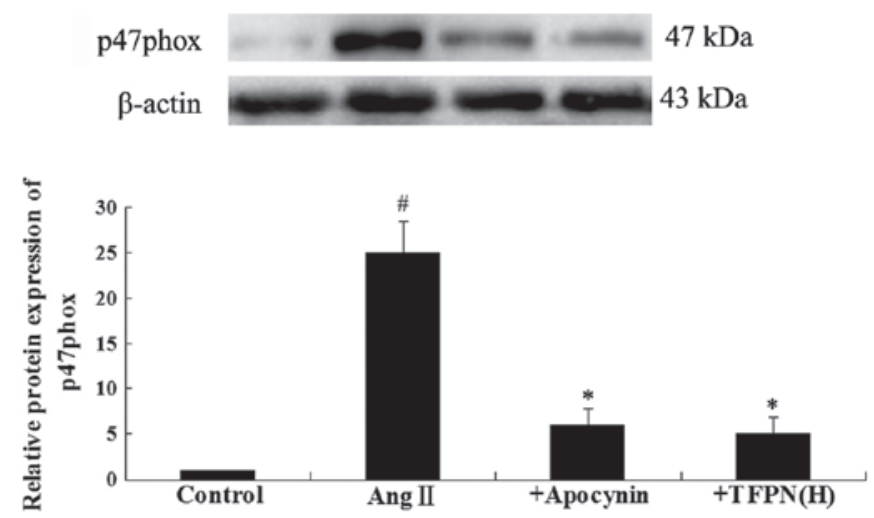

Figure 6. Cells were pretreated with $100 \mu \mathrm{M}$ apocynin and $0.2 \mathrm{mg} / \mathrm{ml}$ TFPN for $4 \mathrm{~h}$. Ang II $\left(10^{-7} \mathrm{~mol} / \mathrm{l}\right)$ was added to the medium for additional $24 \mathrm{~h}$ prior to protein isolation. The gels represent the western blot analysis results of p47phox protein expression. $\beta$-actin was used as the internal control. ${ }^{\prime} \mathrm{P}<0.01$, vs. control; ${ }^{*} \mathrm{P}<0.05$, vs. Ang II; $(\mathrm{n}=3)$. +Apocynin, Ang II + apocynin; $+\mathrm{TFPN}(\mathrm{H})$, Ang II $+0.2 \mathrm{mg} / \mathrm{ml}$ TFPN; TFPN, total flavonoids of Plumula Nelumbinis; Ang II, angiotensin II.

with $50 \mu \mathrm{M}$ PDTC and $100 \mu \mathrm{M}$ apocynin markedly blocked the Ang II-induced expression of FKN $(\mathrm{P}<0.05)$.

p47phox relative protein expression. To clarify whether oxidase activation is involved in the effect of $0.2 \mathrm{mg} / \mathrm{ml}$ TFPN on Ang II-induced FKN elevation, western blotting for p47phox (a subunit of NADPH oxidase) was performed. As shown in Fig. 6, $10^{-7} \mathrm{~mol} / 1$ Ang II significantly increased the protein expression of $\mathrm{p} 47 \mathrm{phox}(\mathrm{P}<0.01)$. Pretreatment with $0.2 \mathrm{mg} / \mathrm{ml} \mathrm{TFPN}$ and $100 \mu \mathrm{M}$ apocynin markedly blocked the Ang II-induced expression of p47phox $(\mathrm{P}<0.05)$.

$I \kappa B-\alpha$ relative protein expression. To clarify the mechanism of the TFPN-associated reduction in FKN protein, western
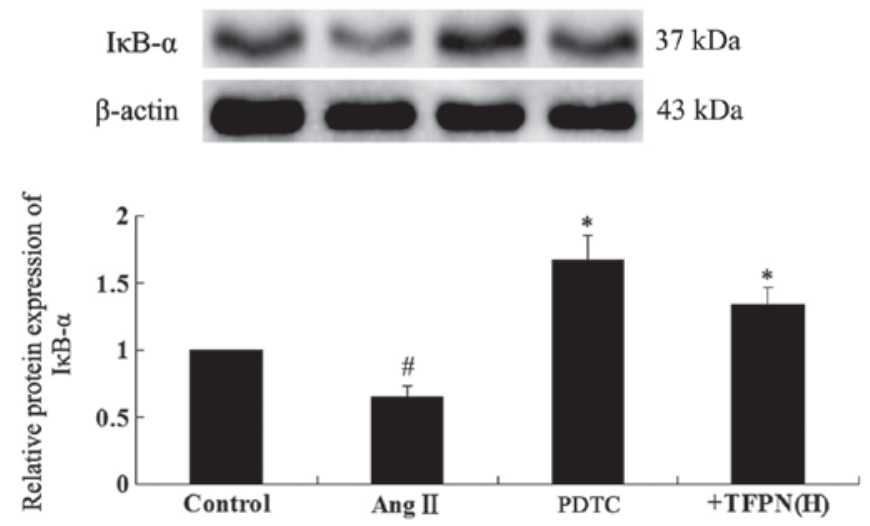

Figure 7. Cells were pretreated with $50 \mu \mathrm{M}$ PDTC and $0.2 \mathrm{mg} / \mathrm{ml}$ TFPN for $4 \mathrm{~h}$. Ang II $\left(10^{-7} \mathrm{~mol} / \mathrm{l}\right)$ was added to the medium for an additional $24 \mathrm{~h}$ prior to protein isolation. The gels represent the western blot analysis results of I $\mathrm{B}-\alpha$ protein expression. $\beta$-actin was used as the internal control. ${ }^{*} \mathrm{P}<0.01$, vs. control; ${ }^{*} \mathrm{P}<0.01$, vs. Ang II; $(\mathrm{n}=3)$. +PDTC, Ang II + PDTC; +TFPN(H), Ang II + $0.2 \mathrm{mg} / \mathrm{ml}$ TFPN; TFPN, Plumula Nelumbinis; Ang II, angiotensin II; PDTC, pyrrolidine dithiocarbamate.

blotting for I $\kappa \mathrm{B}-\alpha$ (an endogenous inhibitor of NF- $\kappa \mathrm{B}$ ) was applied. As shown in Fig. 7, 10-7 mol/1 Ang II significantly decreased the protein expression level of IкB- $\alpha(\mathrm{P}<0.01)$. Pretreatment with $0.2 \mathrm{mg} / \mathrm{ml}$ TFPN inhibited the reduction of the IкB- $\alpha$ level induced by Ang II $(\mathrm{P}<0.01)$ and the same effect was also observed when the cells were pretreated with $50 \mu \mathrm{M}$ PDTC $(\mathrm{P}<0.01)$.

\section{Discussion}

The present study showed that Ang II activated p47phox and increased DCF-sensitive cellular ROS, MDA and FKN expression in HUVECs. However, SOD and IкB- $\alpha$ expression decreased following treatment with Ang II. The results of the present study indicate that the expression of FKN was regulated through the generation of NF- $\mathrm{KB}$ activated by ROS. The administration of each of TFPN, PDTC and apocynin alone significantly reduced the cellular oxidative responses to Ang II.

Endothelial dysfunction is the foundation and initial step of numerous cardiovascular diseases, and promotes abnormal vascular growth, leading to end-organ damage $(10,11)$. However, the underlying molecular mechanisms remain poorly understood. Increasing evidence supports the critical roles of oxidative stress in endothelial dysfunction (12). Endothelial cells are involved in oxidative injury and serve as an important source of arterial oxidative stress (13). Endothelial oxidative stress increases cell apoptosis and the expression of inflammatory cytokine genes, inducing the arteries to fail, relax or dilate, resulting in increased tension of the arterial wall (14). Vascular smooth muscle cells proliferate due to endothelial dysfunction, which further increases the stiffness of the arteries (15). As a result, blood pressure increases.

Xanthine oxidase, uncoupled nitric oxide synthase and NADPH oxidase are likely potential endothelial ROS sources, with NADPH oxidase being the most significant (16). NADPH oxidase is an inducible electron transport system, which transfers reducing equivalents from NADPH to molecular oxygen 
via flavins, resulting in ROS generation (17). The expression and activation of NADPH oxidase has been demonstrated in a number of cell lines, including endothelial cells, vascular smooth muscle cells and cardiomyocytes (18). In endothelial cells, the upregulation of NADPH oxidase may be required for the expression of pro-inflammatory factors or chemokines induced by a neuroendocrine factor, such as Ang II (19).

The results of the present study showed that apocynin prevented the induction of FKN expression by Ang II in endothelial cells, indicating that $\mathrm{FKN}$ is responsive to NADPH oxidase activation with the potential involvement of ROS. PDTC was also found to reduce NF- $\mathrm{B}$-dependent FKN expression, which is consistent with results reported in previous studies (20-22). In endothelial cells, there are several transcriptional factor-binding sites in the cytokine promoter, including one for $N F-\kappa B(23)$. Activated $N F-\kappa B$ may bind to the cytokine promoter, which is critically involved in cytokine gene regulation by various stimuli, such as Ang II. ROS have been hypothesized to be secondary messengers leading to $\mathrm{NF}-\kappa \mathrm{B}$ activation in response to extracellular stimuli and then upregulating the gene expression of chemokines (24). Although PDTC is a well-known inhibitor of $\mathrm{NF}-\kappa \mathrm{B}$, it has been shown that PDTC suppresses NF- $\kappa \mathrm{B}$ activation partly through its antioxidant property, which may account for the reduced ROS formation (25). In the present study, Ang II increased the production of intracellular ROS and induced FKN expression in the endothelial cells; these effects were suppressed by antioxidant agents.

Flavonoids are broad-spectrum antioxidants and anti-inflammatory agents that are known to have efficacy in a number of inflammatory disease models, including coronary heart disease and hypertension (4-8). Moreover, the ethanol extracts from Plumula Nelumbinis have antioxidant and anti-inflammatory functions (26). The current study also indicated the antioxidant property of TFPN, which are the total flavonoids extracted from Plumula Nelumbinis. It was observed that TFPN inhibited the expression of the p47phox subunit of NADPH oxidase, ROS and MDA, while increasing the production of SOD, an oxyradical scavenger, and I $\mathrm{B}-\alpha$, an endogenous $\mathrm{NF}-\kappa \mathrm{B}$ inhibitor. Oxygen radicals are hypothesized to participate in the regulation of $\mathrm{NF}-\kappa \mathrm{B}$, inflammatory factors and chemokines through a NADPH oxidase-dependent pathway. Moreover, the results indicate that the effects of TFPN against NF- $\kappa \mathrm{B}$ and FKN are associated with their antioxidant properties. The antioxidative effect of TFPN may be significant in the mechanism by which they prevent arterial inflammation and endothelial dysfunction.

The suppressive effects of TFPN on cellular oxidative stress and the inflammatory response to Ang II are significant. A series of studies regarded Ang II, which was selected as the cytokine stimulator of ROS in the present study, as one of the important inductive agents of oxidative stress and endothelial dysfunction in vitro and in vivo (1,2,27-29). ROS generation is one of the major mechanisms involved in Ang II-induced tissue damage (28). Ang II also contributes to ROS-dependent vascular smooth muscle cell proliferation in hypertension (29). These results indicate that the effects of Ang II on superoxide production are mediated through NADPH oxidase.

In the present study, TFPN were observed to attenuate the FKN expression induced by Ang II in endothelial cells in a concentration-dependent manner. Furthermore, TFPN decreased FKN expression at similar levels to apocynin and PDTC, indicating that the antioxidant effects of TFPN may be mediated via multiple mechanisms.

Inflammation and oxyradicals contribute to hypertension. FKN, a pleomorphic chemokine, contributes to endothelial dysfunction by inducing inflammatory responses in atherosclerotic disease (30). Previously, FKN levels were found to be increased in spontaneously hypertensive rats, indicating that FKN plays a role in hypertension (31). Furthermore, FKN has been shown to induce ROS production in arteries in vitro (32). The suppressive action of TFPN on FKN implies the prospect of the application of TFPN in the treatment of hypertension.

In conclusion, for the first time to the best of our knowledge, the present study reported that TFPN attenuate Ang II-induced ROS production and thus, ROS-induced $\mathrm{NF}-\kappa \mathrm{B}$ and FKN expression. TFPN exhibit these effects in HUVECs by a radical-scavenging mechanism through an NADPH oxidase-dependent process, indicating that TFPN may become a promising agent for the prevention of endothelial dysfunction.

\section{Acknowledgements}

The study was supported by a grant from the Natural Science Foundation of Hunan Province, China (no. 12JJ5070).

\section{References}

1. Rajagopalan S, Kurz S, Münzel T, et al: Angiotensin II-mediated hypertension in the rat increases vascular superoxide production via membrane NADH/NADPH oxidase activation. Contribution to alterations of vasomotor tone. J Clin Invest 97: 1916-1923, 1996.

2. Touyz RM and Briones AM: Reactive oxygen species and vascular biology: implications in human hypertension. Hypertens Res 34: 5-14, 2011.

3. Wang J, Hu X, Yin W and Cai H: Alkaloids of plumula Nelumbinis. Zhongguo Zhong Yao Za Zhi 16: 673-675, 703, 1991 (In Chinese).

4. Lebeau J, Furman C, Bernier JL, Duriez P, Teissier E and Cotelle N: Antioxidant properties of di-tert-butylhydroxylated flavonoids. Free Radic Biol Med 29: 900-912, 2000.

5. Owen RW, Haubner R, Mier W, et al: Isolation, structure elucidation and antioxidant potential of the major phenolic and flavonoid compounds in brined olive drupes. Food Chem Toxicol 41: 703-717, 2003.

6. Bergman M, Perelman A, Dubinsky Z and Grossman S: Scavenging of reactive oxygen species by a novel glucurinated flavonoid antioxidant isolated and purified from spinach. Phytochemistry 62: 753-762, 2003.

7. Dugas AJ Jr, Castañeda-Acosta J, Bonin GC, Price KL, Fischer NH and Winston GW: Evaluation of the total peroxyl radical-scavenging capacity of flavonoids: structure-activity relationships. J Nat Prod 63: 327-331, 2000.

8. Mishra B, Priyadarsini KI, Kumar MS, Unnikrishnan MK and Mohan H: Effect of O-glycosylation on the antioxidant activity and free radical reactions of a plant flavonoid, chrysoeriol. Bioorg Med Chem 11: 2677-2685, 2003.

9. Jia SJ, Jiang DJ, Hu CP, et al: Lysophosphatidylcholine-induced elevation of asymmetric dimethylarginine level by the NADPH oxidase pathway in endothelial cells. Vascul Pharmacol 44: 143-148, 2006

10. Park JB, Charbonneau F and Schiffrin EL: Correlation of endothelial function in large and small arteries in human essential hypertension. J Hypertens 19: 415-420, 2001.

11. Tomita N, Yamasaki K, Osako MK, Komai N, Shimosato T and Morishita R: Combination therapy based on the angiotensin receptor blocker olmesartan for vascular protection in spontaneously hypertensive rats. Mol Med Rep 2: 733-738, 2009. 
12. Guzik TJ, West NE, Black E, et al: Vascular superoxide production by NAD(P)H oxidase: association with endothelial dysfunction and clinical risk factors. Circ Res 86: E85-E90, 2000.

13. Cai $\mathrm{H}$ and Harrison DG: Endothelial dysfunction in cardiovascular diseases: the role of oxidant stress. Circ Res 87: 840-844, 2000.

14. Guzik TJ, Hoch NE, Brown KA, et al: Role of the T cell in the genesis of angiotensin II induced hypertension and vascular dysfunction. J Exp Med 204: 2449-2460, 2007.

15. Griendling KK, Minieri CA, Ollerenshaw JD and Alexander RW: Angiotensin II stimulates NADH and NADPH oxidase activity in cultured vascular smooth muscle cells. Circ Res 74: 1141-1148, 1994.

16. Shi Y, Niculescu R, Wang D, Patel S, Davenpeck KL and Zalewski A: Increased NAD $(\mathrm{P}) \mathrm{H}$ oxidase and reactive oxygen species in coronary arteries after balloon injury. Arterioscler Thromb Vasc Biol 21: 739-745, 2001.

17. Ohtsu H, Frank GD, Utsunomiya $H$ and Eguchi $S$ : Redox-dependent protein kinase regulation by angiotensin II: mechanistic insights and its pathophysiology. Antioxid Redox Signal 7: 1315-1326, 2005.

18. Lassègue $B$ and Clempus RE: Vascular NAD $(\mathrm{P}) \mathrm{H}$ oxidases: specific features, expression, and regulation. Am J Physiol Regul Integr Comp Physiol 285: R277-R297, 2003.

19. Kalinowski L and Malinski T: Endothelial NADH/NADPH-dependent enzymatic sources of superoxide production: relationship to endothelial dysfunction. Acta Biochim Pol 51: 459-469, 2004.

20. Chandrasekar B, Mummidi S, Perla RP, et al: Fractalkine (CX3CL1) stimulated by nuclear factor kappaB (NF-kappaB)-dependent inflammatory signals induces aortic smooth muscle cell proliferation through an autocrine pathway. Biochem J 373: 547-558, 2003

21. Garcia GE, Xia Y, Chen S, et al: NF-kappaB-dependent fractalkine induction in rat aortic endothelial cells stimulated by IL-1beta, TNF-alpha, and LPS. J Leukoc Biol 67: 577-584, 2000.

22. Zernecke A, Weber KS and Weber C: Combined modulation of the mesangial machinery for monocyte recruitment by inhibition of NF-kappaB. Am J Physiol Cell Physiol 281: C1881-C1888, 2001.
23. Pomerantz JL and Baltimore D: Two pathways to NF-kappaB. Mol Cell 10: 693-695, 2002.

24. Bonello S, Zähringer C, BelAiba RS, et al: Reactive oxygen species activate the HIF-1alpha promoter via a functional NFkappaB site. Arterioscler Thromb Vasc Biol 27: 755-761, 2007.

25. Yokoo T and Kitamura M: Antioxidant PDTC induces stromelysin expression in mesangial cells via a tyrosine kinase-AP-1 pathway. Am J Physiol 270: F806-F811, 1996.

26. Chen J, Zhang M, Zheng T-S and Tao J-H: Study on antioxidant activities of ethanol extracts from lotus germ in vitro. Food Science 29: 48-51, 2008 (In Chinese).

27. Hanna IR, Taniyama Y, Szöcs K, Rocic P and Griendling KK: $\mathrm{NAD}(\mathrm{P}) \mathrm{H}$ oxidase-derived reactive oxygen species as mediators of angiotensin II signaling. Antioxid Redox Signal 4: 899-914, 2002.

28. Ruiz-Ortega M, Ruperez M, Esteban V and Egido J: Molecular mechanisms of angiotensin II-induced vascular injury. Curr Hypertens Rep 5: 73-79, 2003.

29. Luo Z, Teerlink T, Griendling K, Aslam S, Welch WJ and Wilcox CS: Angiotensin II and NADPH oxidase increase ADMA in vascular smooth muscle cells. Hypertension 56: 498-504, 2010.

30. Wong BW, Wong D and McManus BM: Characterization of fractalkine (CX3CL1) and CX3CR1 in human coronary arteries with native atherosclerosis, diabetes mellitus, and transplant vascular disease. Cardiovasc Pathol 11: 332-338, 2002.

31. Sullivan JC, Pardieck JL, Doran D, Zhang Y, She JX and Pollock JS: Greater fractalkine expression in mesenteric arteries of female spontaneously hypertensive rats compared with males. Am J Physiol Heart Circ Physiol 296: H1080-H1088, 2009.

32. Schäfer A, Schulz C, Fraccarollo D, et al: The CX3C chemokine fractalkine induces vascular dysfunction by generation of superoxide anions. Arterioscler Thromb Vasc Biol 27: 55-62, 2007. 